\title{
PRIORITIZATION OF WATERSHED BASED ON SOIL EROSION MODEL: A CASE STUDY OF NOYYAL RIVER BASIN, TAMIL NADU
}

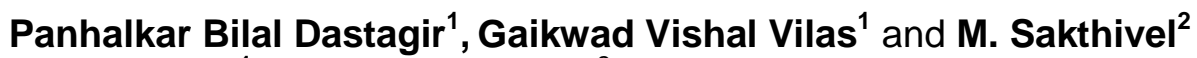 \\ ${ }^{1}$ Research Scholars, ${ }^{2}$ Associate Professor, \\ Dept. of Geography, University of Madras, Chennai, India \\ Email:bilalpanhalkar777@gmail.com
}

\begin{abstract}
Soil Erosion is a universal problem as it poses great risk to cultivable land. Erosion of soil is more prominent along the regions adjacent to water bodies and in hilly areas. Present study is carried out in Noyyal River Basin, Tamil Nadu which covers 3,514 square kilometers of land. The study area lies between $10^{\circ} 54^{\prime} 04^{\prime \prime} N$ to $11^{\circ} 20^{\prime} 13^{\prime \prime} N$ and longitude of $76^{\circ} 36^{\prime} 08^{\prime \prime} \mathrm{E}$ to $77^{\circ} 56^{\prime} 16^{\prime \prime}$ E latitude. Average annual soil loss for the study area is calculated using 5 parameters of Rainfall Erosivity Factor $(R)$, Soil Erodibility Factor (K), Slope Length and Steepness Factor (LS), Cover Management Factor (C) and Conservation Practice Factor (P) using Revised Universal Soil Loss Equation (RUSLE) Model. The soil erosion risk factor was classified into 4 risk classes of slight (0-0.5 ton/ha/year), Moderate (0.5-10 ton/ha/year), High (10-80 ton/ha/year) and Very High (>80 ton/ha/year). It was found that majority of the study area falls under the category of slight erosion and moderate erosion. The result of Annual Soil Loss obtained through GIS platform is further analyzed for prioritization of watersheds. The entire river basin was divided in 18 Sub-Watersheds. These watersheds are classified into Low (0-80 ton/ha/year), Moderate (80-180 ton/ha/year) and High (>180 ton/ha/year) Priorities based on the mean annual soil loss of the particular watershed.
\end{abstract}

Key words: Soil Erosion Model, P-Factor, LU/LC, Prioritization of Watershed.

\section{Introduction}

Soil is the uppermost layer of the earth crust, consisting weathered rocks and minerals with organic substances and forms one of the most vital resource for the existence of life on the earth. Soil, although being one of vital resource is highly prone to water erosion. Soil and water interact with each other in various phases, most important being the hydrological cycle. When soil and water interact in hydrological cycle the water detaches and carries away soil particles. These particles get settled on the bed of the stream, thereby reducing its capacity which further accelerates to floods and on the other side causes loss of rich fertile soil. Soil loss is deliberated as a heavier real question as it incredibly threatens physical resources, agricultural, grassland, forest and environmental. Soil loss is a process of variables parameters rainfall, runoff, close relative element, soil features, terrain, plantation, and land cover. Soil loss is deeply fallen because of bio- physical and socioeconomic factors, e.g., pasturage, agriculture system, and impoverishment. (Narayan Kayet et.al, 2018). USLE model has predicted soil erosion through the water and RUSEL also fallow the same principle but contain a several improvement in calculation for various factor. Soil erosion is a vital and non-renewable resource in the earth but in many region people did not consider soil erosion and land degradation problems for that causes vast area economically unproductive so that region consider to give more priority for management and improve soil productivity. Geo information techniques widely use to assess the soil loss intended for all the region and recently availability of high resolution data has used to make a large scale inventory of Digital Elevation Model (DEM), land use/land cover (LULC) and soil resource maps were effectively used to assessed soil erosion hazard (P. Karthick et. al, 2017). The aim of the present study was, to determine the spatial distribution of annual soil loss and to analyze the effect of Rainfall, land use cover, slope exposition and terrace farming on soil erosion using RUSLE model and Geo-information technology. 


\section{Study Area}

The Noyyal River Basin is situated on the North and East Hemisphere located between latitude of $10^{\circ} 54^{\prime} \mathrm{C} 4^{\prime \prime} \mathrm{N}$ to $11^{\circ} 20^{\prime} 13^{\prime \prime} \mathrm{N}$ and longitude of $76^{\circ} 36^{\prime} 08^{\prime \prime} \mathrm{E}$ to $77^{\circ} 56^{\prime} 16^{\prime \prime} \mathrm{E}$. The Noyyal River is a small river in Western Tamil Nadu, and a tributary of Kaveri River. It rises from the Vellingiri hills in the Western Ghats in Tamil Nadu, very close to Kerala border, and flows through many villages and the cities of Coimbatore, and Tirupur finally draining into the Kaveri River at Noyyal, a village in Karur district named after the river itself. The river's basin is $180 \mathrm{~km}$. long and $25 \mathrm{~km}$ wide and covers a total area of $3,514 \mathrm{sq} . \mathrm{km}$. Cultivated land in the basin amounts to $1,800 \mathrm{sq}$. $\mathrm{km}$ while the population density is 120 people per sq. $\mathrm{km}$. in the countryside, and 1000 people per sq. $\mathrm{km}$. in the cities. The area is known for its scanty rainfall and the development of the Noyyal River Tanks System to hold any overflow from the rains plus the water of the Northeast and Southwest monsoon season was ecologically important. The $173 \mathrm{~km}$. long tributary of the Kaveri River filled 32 tanks. These interconnecting tanks held the water flowing from the Noyyal.

Figure 01: Location Map of Study Area

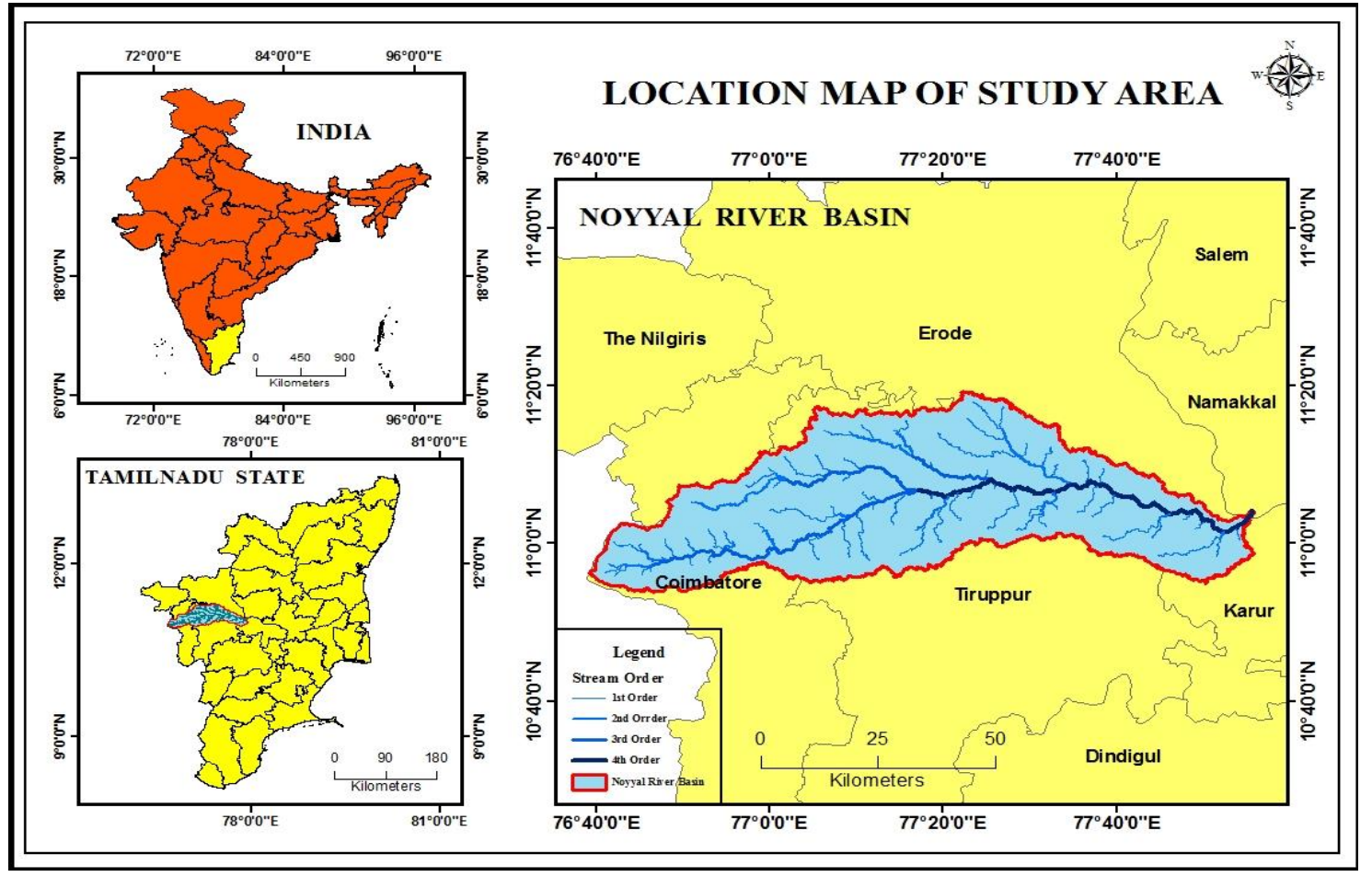

\section{Objectives of the Study}

- To Estimate of the average annual soil loss from the Noyyal River basin and its spatial distribution.

- Prioritization of sub watersheds of Noyyal River basin based on degree of severity of soil erosion for watershed treatment.

- To suggest specific conservation practices to minimize the soil erosion rate.

\section{Materials and Methods}

Table 01: Required Dataset for Soil Erosion Model

\begin{tabular}{|c|l|l|l|}
\hline$\#$ & \multicolumn{1}{|c|}{ Datasets } & \multicolumn{1}{c|}{ Source } & \multicolumn{1}{c|}{ Resolution/ Data types } \\
\hline 1. & $\begin{array}{l}\text { Rainfall Data } \\
\text { (2000 To 2018) }\end{array}$ & $\begin{array}{l}\text { State Ground \& Surface Water } \\
\text { Resources Data Center, Taramani. }\end{array}$ & Excel Format \\
\hline 2. & Soil data & $\begin{array}{l}\text { Soil and Land use } \\
\text { survey of India, Bangalore }\end{array}$ & .shp \& Excel Format \\
\hline 3. & ASTER - DEM & https://earthexplorer.usgs.gov. & 30 Meter \\
\hline 4. & $\begin{array}{l}\text { Sentinel - 2A } \\
\text { (Satellite Image) }\end{array}$ & https://earthexplorer.usgs.gov. & 10 Meter \\
\hline
\end{tabular}




\section{Rainfall Erosivity Factor (R)}

The soil loss is closely related to rainfall detaching power of raindrop striking the soil surface which is the contribution of rain to runoff. The most suitable expression of the erosivity of rainfall is an index based on kinetic energy of the rain. There are different ways of analyzing the $R$ factor. For instance,

$$
\mathrm{R}=79+0.363^{*} \mathrm{Xa} \ldots \text {... Eq. (1) }
$$

Where Xa is Average Annual Rainfall (MM) [Chaudhary and Nayak, (2003)]

These formulas have been applied in different parts of the India. Whereas, the application for other countries are less satisfactory. Especially with the annual rainfall below $900 \mathrm{~mm}$, like part of the study area, the equation yields estimates of erosivity, which are obviously meaningless.

\section{Soil Erodibility factor (K)}

Soil erodibility factor $(\mathrm{K})$ signifies the sensitivity of soil or surface components to erosion, transportability of the silt, and the quantity and amount of runoff assumed an individual rainfall contribution as calculated in a standard condition. Soil texture is critical for hydrologic soil group determination. Soil textures were classified by the fractions of each soil different present in the soil. $\mathrm{K}$ parameter is determinate by various soil characteristic similar to the texture of soil or particle size allocation, organic matter amount, penetrability, and environment of clay minerals, of which soil texture is the significant issue for standardized soil erodibility.

Where,

$$
\begin{gathered}
\mathrm{K}=27: 66 * \mathrm{M}^{1.14 *} 10^{-8 *}(12-\mathrm{A})+\left(0.0043^{*} \mathrm{~B}-2\right)+(0.0033 *(\mathrm{C}-3)) \ldots . \text { Eq. }(2) \\
{[\text { Narayan Kayet et al. }(2018)]}
\end{gathered}
$$

$\mathbf{M}=$ silt (\%) + very fine sand (\%) *(100-clay (\%)),

A is organic matter (\%),

B is structure code

1. Very structured or particulate,

2. relatively structured

3. Slightly formal

4. Solid.

C is profile permeability system rapid, moderate to rapid, moderates, moderate to slow, slow and very slow.

\section{Slope length and steepness (LS) Factor}

LS factor depends on the slope length and steepness of the area and it has played an important role in soil erosion. They produce for topography on the top soil erosion and its containing the length and steepness of the slope that persuade the surface runoff speed. The RUSLE formulate that no separation among the rill and inter rill in the $S$ factor that compute the consequence of slope steepness in the soil loss. The study area LS factor was prepared through ASTER DEM (30 m Resolution) data its show in Figure-10. There are lots of relationships for the assessment of LS factor while the best suitable for intergraded with GIS platform it is proposed by Moore et al.22. It's based on the unit stream power theory that equation as follows:

Where

$$
L S=(A / 22.13)^{0.6}+(\sin (B \times 0.01745 / 0.0896))^{1.3} \ldots . \text { Eq. }(3)
$$

A is a slope length factor,

B is the slope steepness factor;

22.13 is the RUSLE unit plot length,

0.6 is the slope length

Exponent variable (generally it's taken from respective grid).

$\mathbf{A}=$ (Flow accumulation $\times$ grid size $)$

$\mathbf{B}=$ Slope of DEM 
The accuracy can be estimated through the digital elevation model (DEM) data resolution. Arc GIS Raster calculator tool used to drive LS factor map it's based on the slope steepness and flow accumulation.

\section{Cover and Management (C) Factor}

The cover and management factor are an important factor for reduction of soil erosion and it depends on land use pattern of an area. The $C$ factor is the ratio of soil loss from an area with protective cover and management to soil loss in the continuous clean tilled fallow land. The values of $C$ factor vary from 0 to 1 based on land use land cover types without including areas of water body. In this study, Normalized Difference Vegetation Index (NDVI) was used to calculate the $\mathrm{C}$ factor. The equation (4) for calculating the NDVI is:

$$
N D V I=\frac{\text { NIR }- \text { RED }}{\text { NIR }+ \text { RED }} \quad \text { Eq. (4) }
$$

After prepared NDVI, following equation (5) has been used to create $\mathrm{C}$ factor map:

$$
\mathrm{C}=1.20-1.21^{*} \mathrm{NDVI} \quad \text { Eq. (5) }
$$

[Asish Saha et al. (2018)]

\section{Land Use / Land Cover}

Land use refers to human's activities and various uses of land cover. Land cover refers to vegetation cover, water bodies, agricultural land, built-up land cover and others resulting due to land transformation. Although land use is generally inferred based on the cover, yet both the terms land use and land cover are closely related and interchangeable. Thematic land classes can be derived digitally by grouping pixels that have similar spectral signatures from the measurements of individual bands throughout the spectrum. Usually this classification is made with visible, near-infrared, and middle infrared part of the spectrum. The Land Use/Land Cover is classified by supervised classification by using ArcGIS 10.3 software.

\section{Conservation Practice Factor (P)}

The conservation practice factor $(P)$ is the most important parameter in RUSLE method and it is a boundless factor defined $\mathrm{P}$ factor as the ratio of soil loss in a particular support practice to the corresponding soil loss with up and down slope cultivation. P-value ranges from 0 to 1 , where the value 0 indicates good erosion resistant facility made by man and the value 1 indicate an absence of erosion resistant facility.

\section{Results and Discussions \\ Rainfall Erosivity Factor (R)}

The rainfall intensity is the primary factor for estimating the Rainfall erosivity factor. Rainfall erosivity factor indicates the regions of study area that are more prone to erosion due to rainfall. The values of $R$ factor are computed for a range of 206 to 383. 75percent of the region lie in moderate rainfall erosivity regions while there are small pockets of land towards the western region of the study area that have high soil erosivity. Low level of rainfall erosivity is seen towards the eastern region of the study area. Average R-factor for locations in Coimbatore district is 294, Tiruppur district is 278. While the values for Erode and Karur districts are 254 and 288 respectively. Thus, it is fine to say that rainfall intensity in Coimbatore district is comparatively more than other districts; hence the R-factor values are also more. 
Table 02: Station wise Annual Average Rainfall and R - Factor

\begin{tabular}{|c|l|l|c|c|}
\hline$\#$ & Station Name & Districts & $\begin{array}{c}\text { Annual Average } \\
\text { Rainfall (2000 to 2018) }\end{array}$ & R Factor \\
\hline 1. & Annur & Coimbatore & 481.4 & 253.74 \\
\hline 2. & Chithraichavadi Anicut & Coimbatore & 724.1 & 341.86 \\
\hline 3. & Coimbatore Airport & Coimbatore & 588.1 & 292.48 \\
\hline 4. & Agriculture College & Coimbatore & 590.4 & 293.32 \\
\hline 5. & CMC Medical College & Coimbatore & 838.6 & 383.39 \\
\hline 6. & Periyanayakkanpalayam & Coimbatore & 576.3 & 288.18 \\
\hline 7. & Pothanur railway & Coimbatore & 519.6 & 267.61 \\
\hline 8. & Sulur & Coimbatore & 477.9 & 252.48 \\
\hline 9. & Thiruppur & Coimbatore & 554.9 & 280.43 \\
\hline 10. & Avinashi & Tiruppur & 665.1 & 320.44 \\
\hline 11. & Kankeyam & Tiruppur & 543.4 & 276.25 \\
\hline 12. & Mangal Patti & Tiruppur & 349.9 & 206.03 \\
\hline 13. & Palladam & Tiruppur & 582.4 & 290.42 \\
\hline 14. & Pongalur & Tiruppur & 463 & 247.07 \\
\hline 15. & Sundakkampalayam & Tiruppur & 689 & 329.11 \\
\hline 16. & Arachalur & Erode & 366.7 & 212.11 \\
\hline 17. & Chennimalai & Erode & 626.3 & 309.62 \\
\hline 18. & Ichipalayam & Erode & 478.7 & 252.76 \\
\hline 19. & Karur & Karur & 577.7 & 288.71 \\
\hline 20. & K Paramathi(Karur) & Karur & 610.5 & 300.62 \\
\hline 21. & Krishnarayapuram & Karur & 483.8 & 254.63 \\
\hline 22. & Mayanur & Karur & 635.5 & 309.7 \\
\hline
\end{tabular}

Figure 02: Rainfall Erosivity Factor (R)

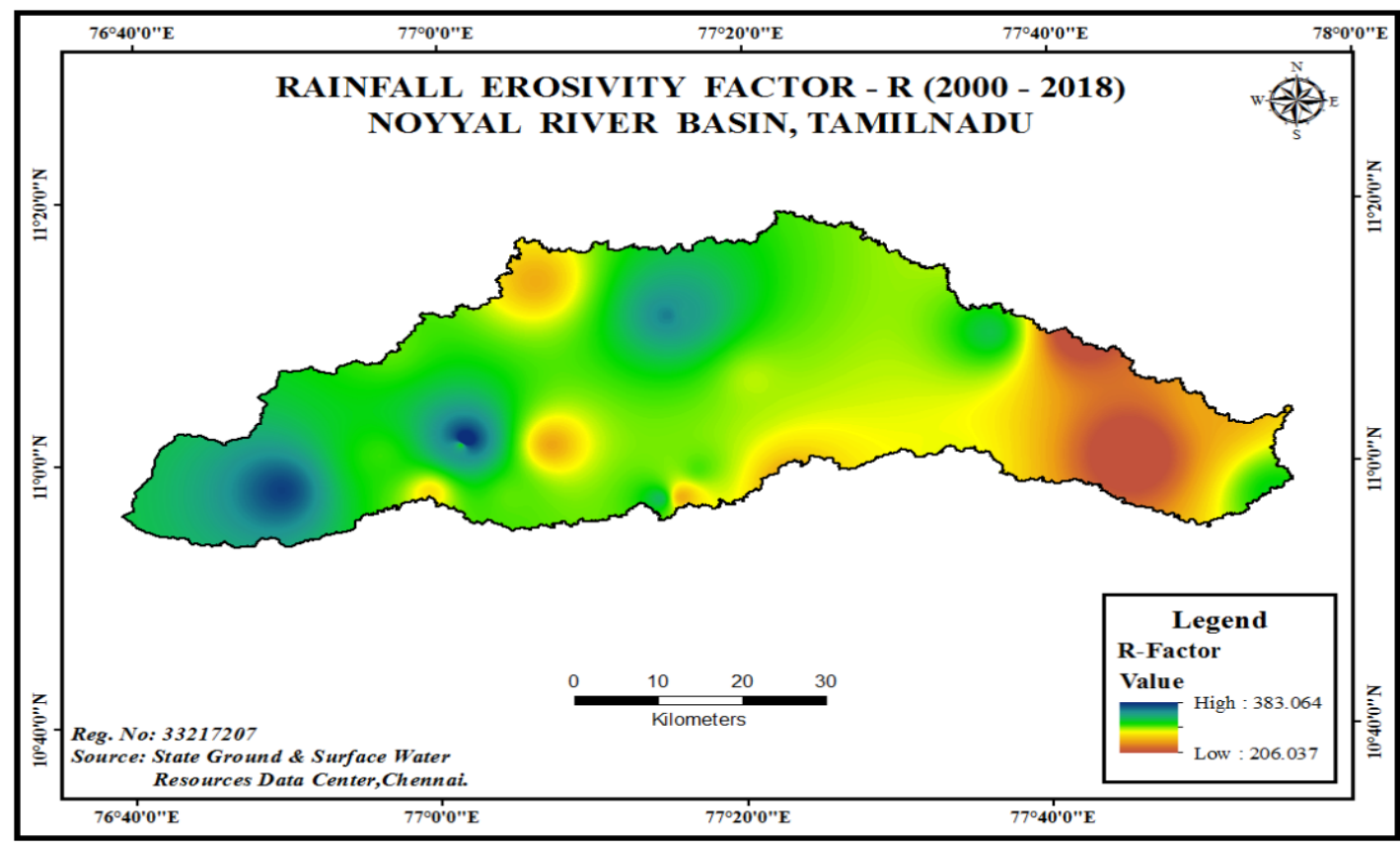

\section{Soil Erodibility Factor (K)}

Soil erodibility factor is the measure of potential erodibility of the soil depending on its inherent soil properties. Soil texture, organic matter and permeability are all factors for computing the soil erodibility factor. $\mathrm{K}$ factor values range from 0.004 to 0.35 . The sandy clay loam soil has the highest $\mathrm{K}$ factor of 0.35 followed by sandy loam and sandy clay of 0.14 and 0.12 values respectively. The lowest $\mathrm{K}$ factor is computed for clay soil with a value of 0.004 . Soils with low clay content are less cohesive and are inherently more unstable, thus making them more vulnerable to erosion through water and wind. Soil with high sand content is not cohesive and has a high value risk of erosion. This is implied by the values obtained using the K-factor. 
Figure 03: Soil Erodibility Factor (K)

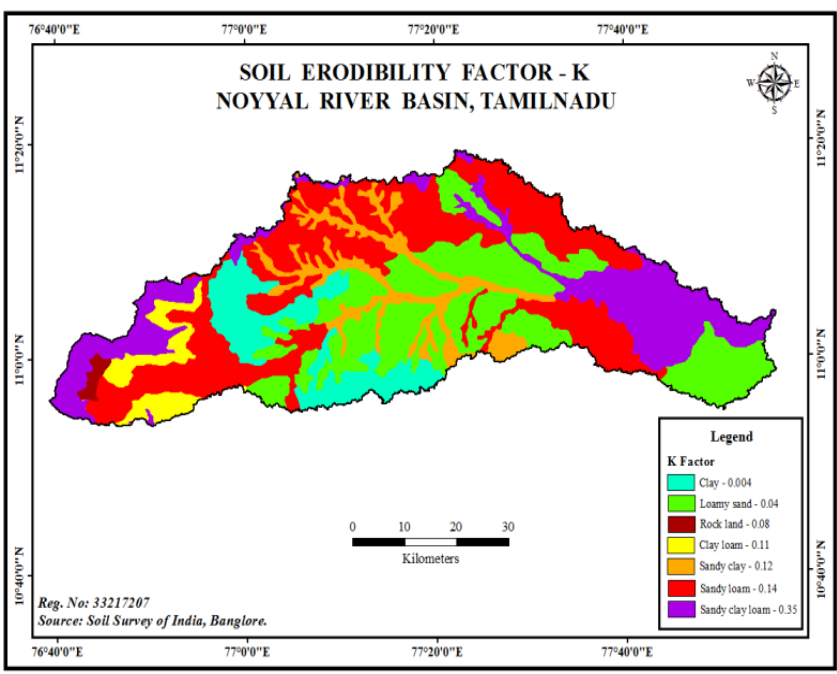

Figure 04: Slope Length and Slope

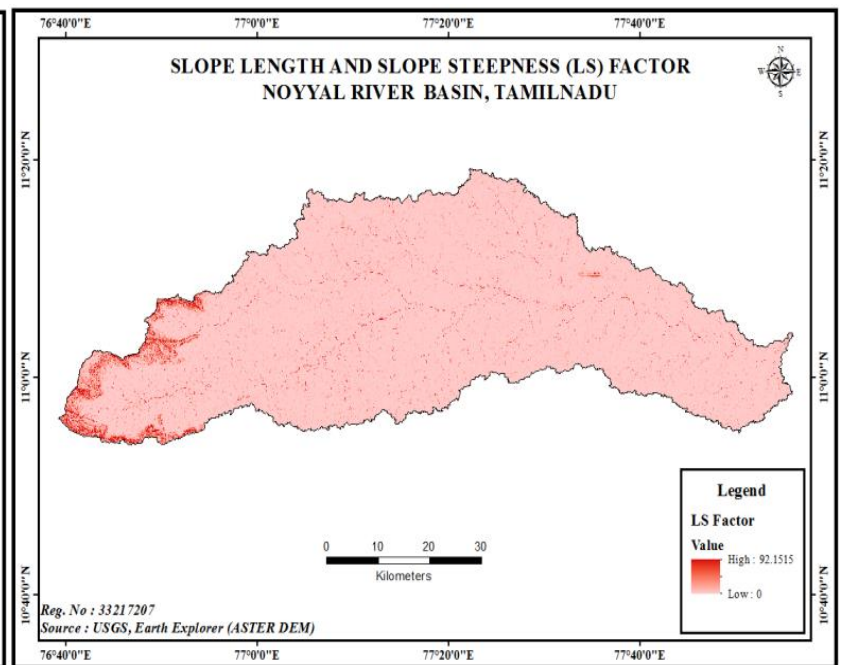

Table 03: K Factor Values

\begin{tabular}{|c|l|c|}
\hline$\#$ & Soil Texture & K Factor \\
\hline 1. & Clay & 0.004 \\
\hline 2. & Loamy Sand & 0.04 \\
\hline 3. & Rock Land & 0.08 \\
\hline 4. & Clay Loam & 0.11 \\
\hline 5. & Sandy Clay & 0.12 \\
\hline 6. & Sandy Loam & 0.14 \\
\hline 7. & Sandy Clay Loam & 0.35 \\
\hline
\end{tabular}

\section{Slope Length and Steepness (LS) Factor}

LS factors include Slope Length and Slope Steepness Factor which mainly reflect the effect of Surface Topography and slope characteristics on erosion by water action. The values of LS factor lie between the range of $0-92$. High values of LS factor are seen in the western region of the map where there is high slope compared to others, indicating a hilly terrain. Thus, it can be interpreted that the values of LS factor are more in the hilly terrain regions as erosion due to water is more in hilly regions or regions with high slope values. Higher the steepness of the slope, more the risk of erosion as the soil particles present in steep slopes are unstable and are subjected to gravitational forces of earth.

\section{Cover and Management (C) Factor}

Cover and Management Factor are important for the reduction of soil erosion as it depends on the land use pattern. The values of $C$ factor range from 0.37-1.2 based on NDVI classes excluding the water bodies in this study area. In this study, C factor is calculated using NDVI, Normalized Difference Vegetation Index. The $C$ factor for the study area is low in the highly vegetated regions while the values of $C$ factor are high in the regions of non-vegetation or low vegetation. Soil erosion is less in highly vegetated regions compared to other regions because the roots of the vegetation hold the soil particles together making them less vulnerable to erosion by wind and water. Regions of low $\mathrm{C}$ factor are found in the western regions of the map; possibly hilly terrain and the regions of high $\mathrm{C}$ factor are found in the eastern and central regions of the study area. Thus, the vegetation cover is an important factor to analyse the soil erosion. 
Figure 05: NDVI Map

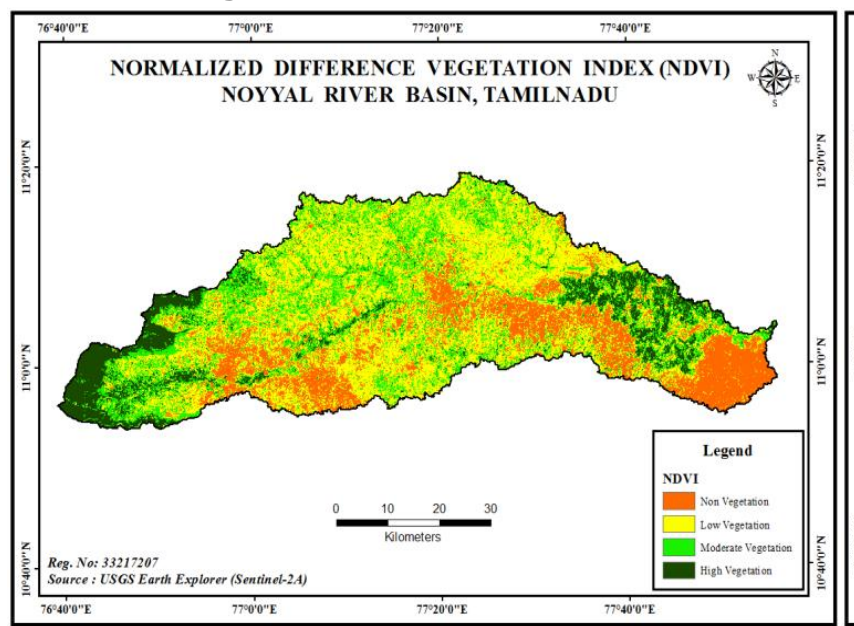

Figure 06: Cover Factor C

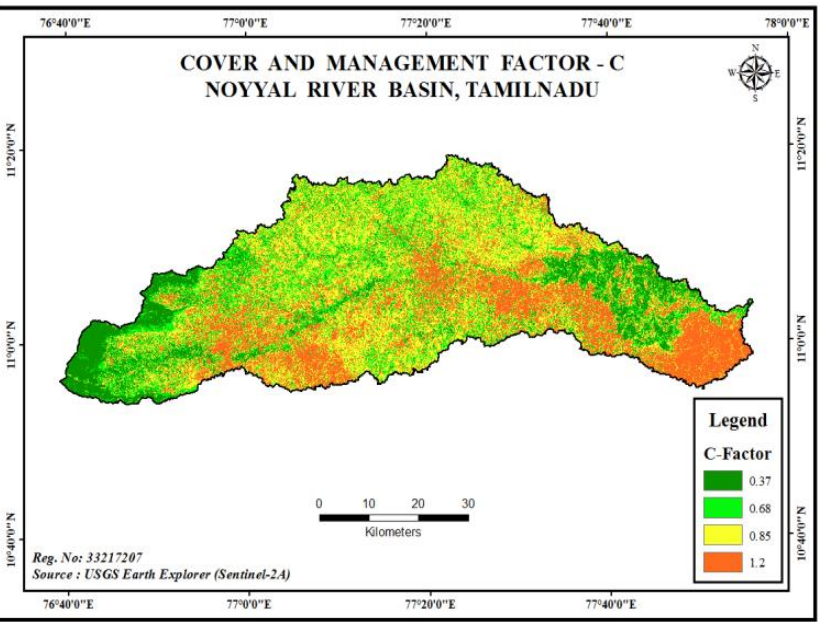

\section{Conservation Practice Factor (P)}

$P$ factor is used to find the areas with good conservation practices deployed by man and the regions that further need steps taken for conservation of soil. The value for regions with good conservation steps is 0.28 and found to be in the agricultural lands. Farmers tend to safeguard the soil from erosion through the setting up of soil bunds etc., ensuring the erosion of soil is prevented to some extent. However, it is clear from the study that region apart from agricultural land misses the same efforts and conservation steps. Forests, Fallow land, Built-up land, rock land all have the value for $p$-factor as 1 , indicating minimum efforts of man in conservation.

Figure 07: LU/LC Map (2018)

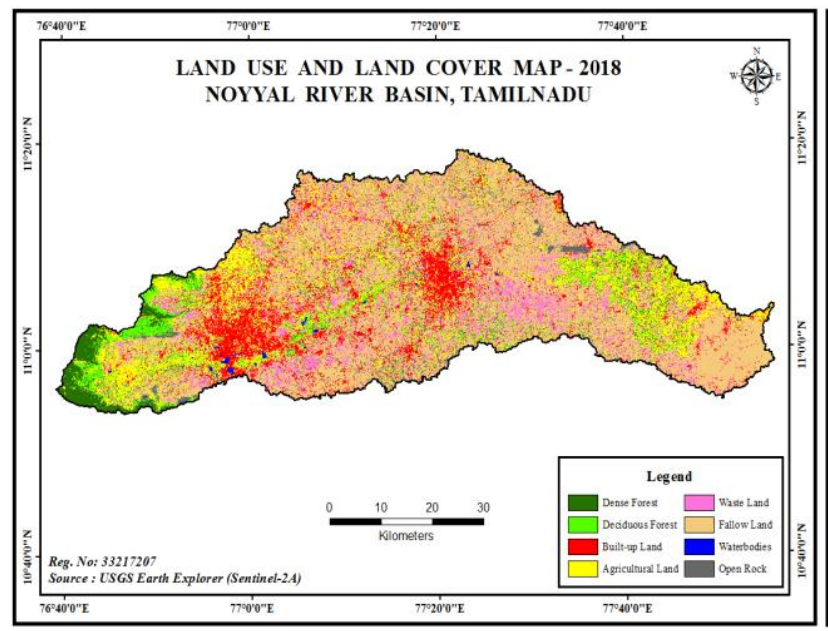

Figure 08: Conservation Practice Factor (P)

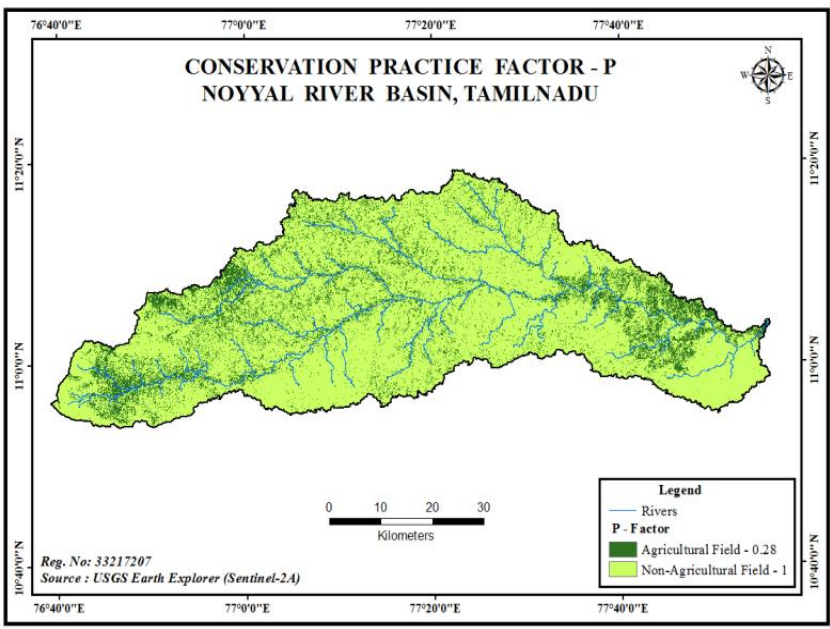

Table 04: LU/ LC of Noyyal River Basin

\begin{tabular}{|c|l|c|}
\hline$\#$ & LU/ LC & Area (sq. $\mathbf{~ k m . )}$ \\
\hline 1 & Dense Forest & 95.816 \\
\hline 2 & Deciduous Forest & 212.56 \\
\hline 3 & Built-up Land & 436.981 \\
\hline 4 & Agricultural Land & 609.491 \\
\hline 5 & Waste Land & 405.226 \\
\hline 6 & Fallow Land & 1486.112 \\
\hline 7 & Waterbodies & 60.447 \\
\hline 8 & Rock land & 206.658 \\
\hline & Total & 3513.291 \\
\hline
\end{tabular}


Table 05: P-Factor values

\begin{tabular}{|c|l|c|c|}
\hline$\#$ & Land Use / Land Cover & Area (sq. $\mathbf{k m})$. & P - Factor \\
\hline 1 & Dense Forest & 95.816 & 1 \\
\hline 2 & Deciduous Forest & 212.56 & 1 \\
\hline 3 & Built-up Land & 436.981 & 1 \\
\hline 4 & Agricultural Land & 609.491 & 0.28 \\
\hline 5 & Waste Land & 405.226 & 1 \\
\hline 6 & Fallow Land & 1486.112 & 1 \\
\hline 7 & Waterbodies & 60.447 & 1 \\
\hline 8 & Rock land & 206.658 & 1 \\
\hline
\end{tabular}

\section{Average Annual Soil Loss (A)}

The R, K, LS, C and P Factors as elements of the RUSLE equation can be considered as naturally occurring factors determining the sheet and rill erosion processes. Together, they can be considered as the erosion susceptibility or potential erosion or soil loss (tons/hectare/year) for the area.

$$
\text { Annual Soil Loss }(A)=R * L S * K * C * P \text {... Eq. (6) }
$$

Figure 09: Potential Soil Erosion Area (2018)

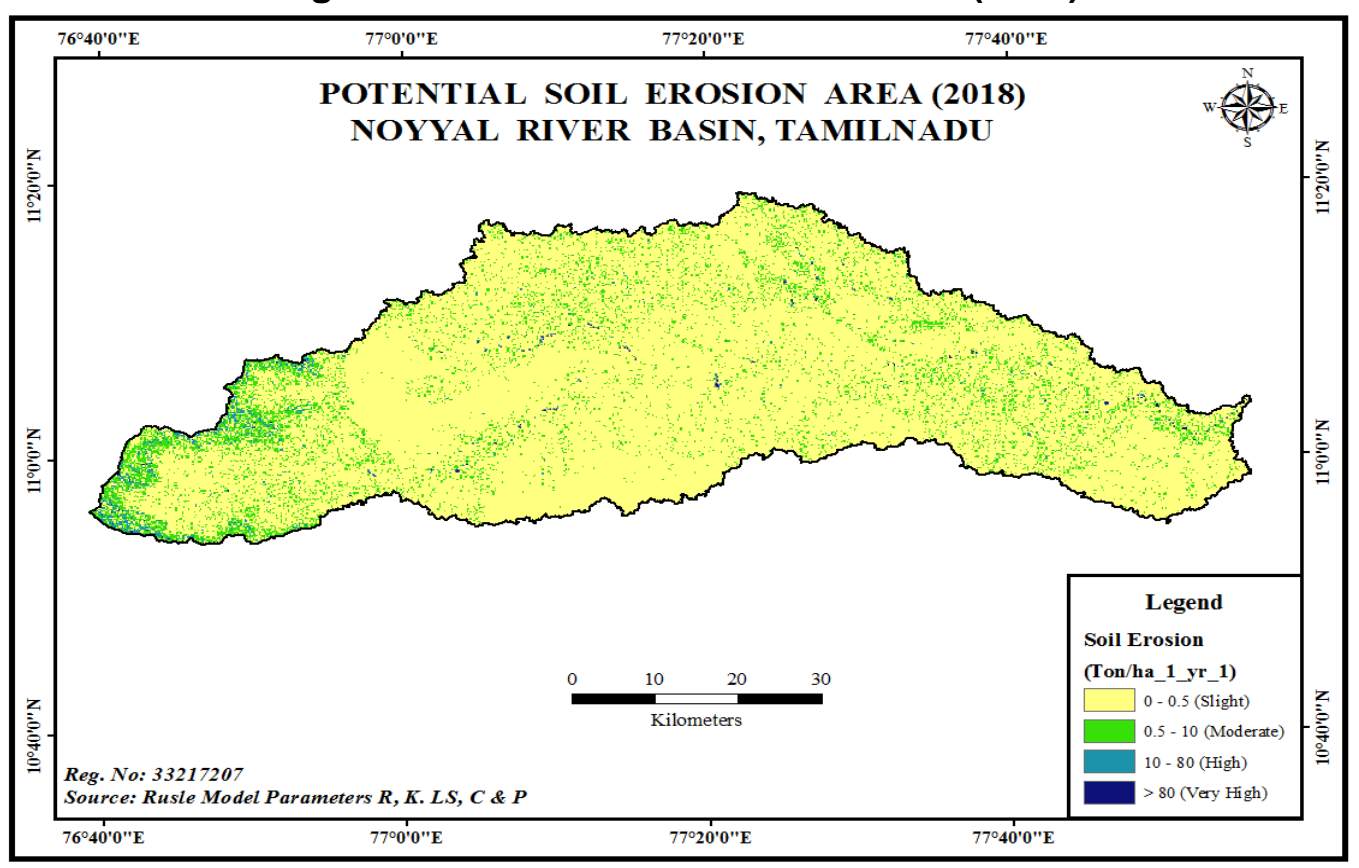

The average soil loss is calculated multiplying all the factors and classified into regions of Slight, Moderate, High and Very High regions. From the analysis, it is interpreted that the majority of the regions in the Noyyal River Basin fall under the category of Slight Soil Erosion Regions with Average Annual Soil Loss up to 0.5 tonnes/hectare. However, few regions towards the western region of the study area that receives higher intensity of rainfall, higher slope (hilly terrain), highly forested regions and regions with minimal conservation practice are found to fall under Moderate Soil Erosion with average annual soil loss value up to 10 tonnes/hectare/year. High vegetation is one of the key factors in this region as it prevents higher levels of soil erosion.

\section{Prioritization of Watershed based on Soil Loss}

The prioritization of watershed in terms of soil loss act as powerful tool for identification of areas which require urgent soil conservation measures to check and restore soil loss. The Noyyal river 
basin was divided into 18 sub-watersheds to identify sub-watersheds, which needs erosion control treatment on priority basis. Distribution of soil loss from this sub-watershed has been depicted in Fig. 10 to Fig. 12. The average annual soil loss from these sub-watersheds have been worked out and presented in Table 6 . The results show that W16 sub-watershed is highest prone to soil loss among all other sub-watersheds. W7 is least prone to soil loss. SW2 is least prone because the topography or the slope in this sub-watershed is flat whereas in W16 the topography is highly undulating hence it is highly prone to soil loss.

Figure 10: Soil Loss of Sub-Watersheds W-1 to W-6

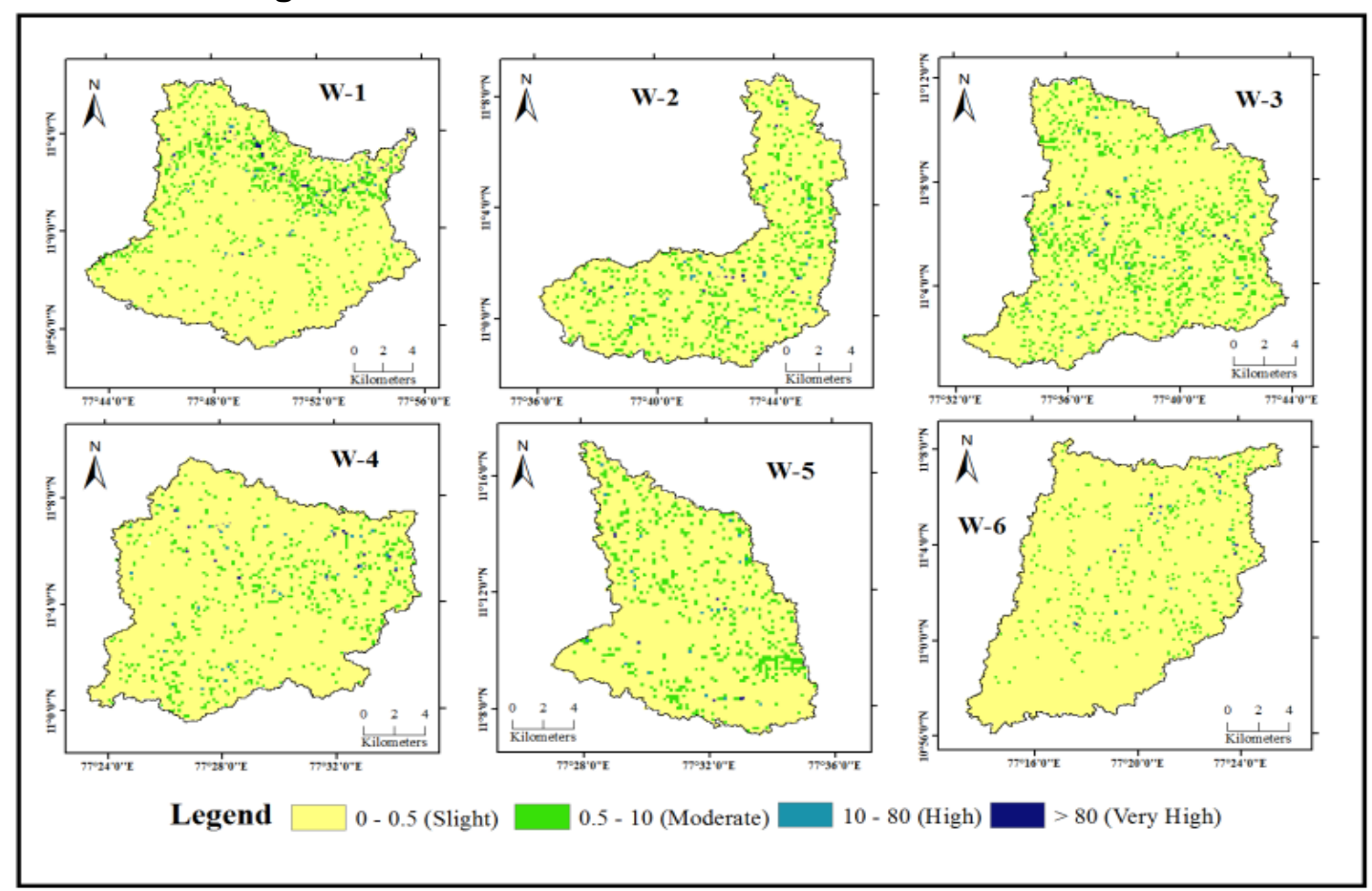

Figure 11: Soil Loss of Sub-Watersheds W-7 to W-12

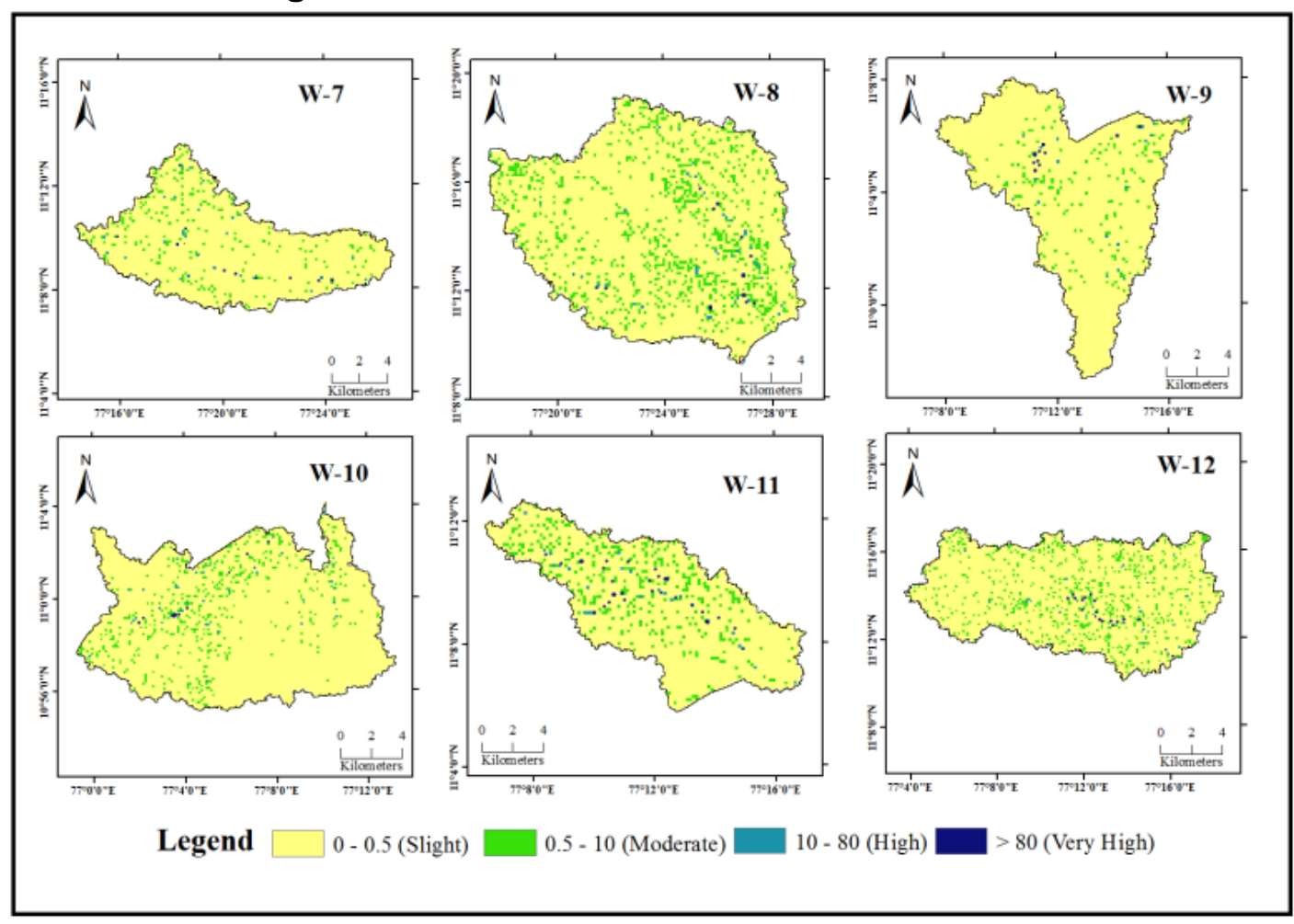


Figure 12: Soil Loss of Sub-Watersheds W-13 to W-18

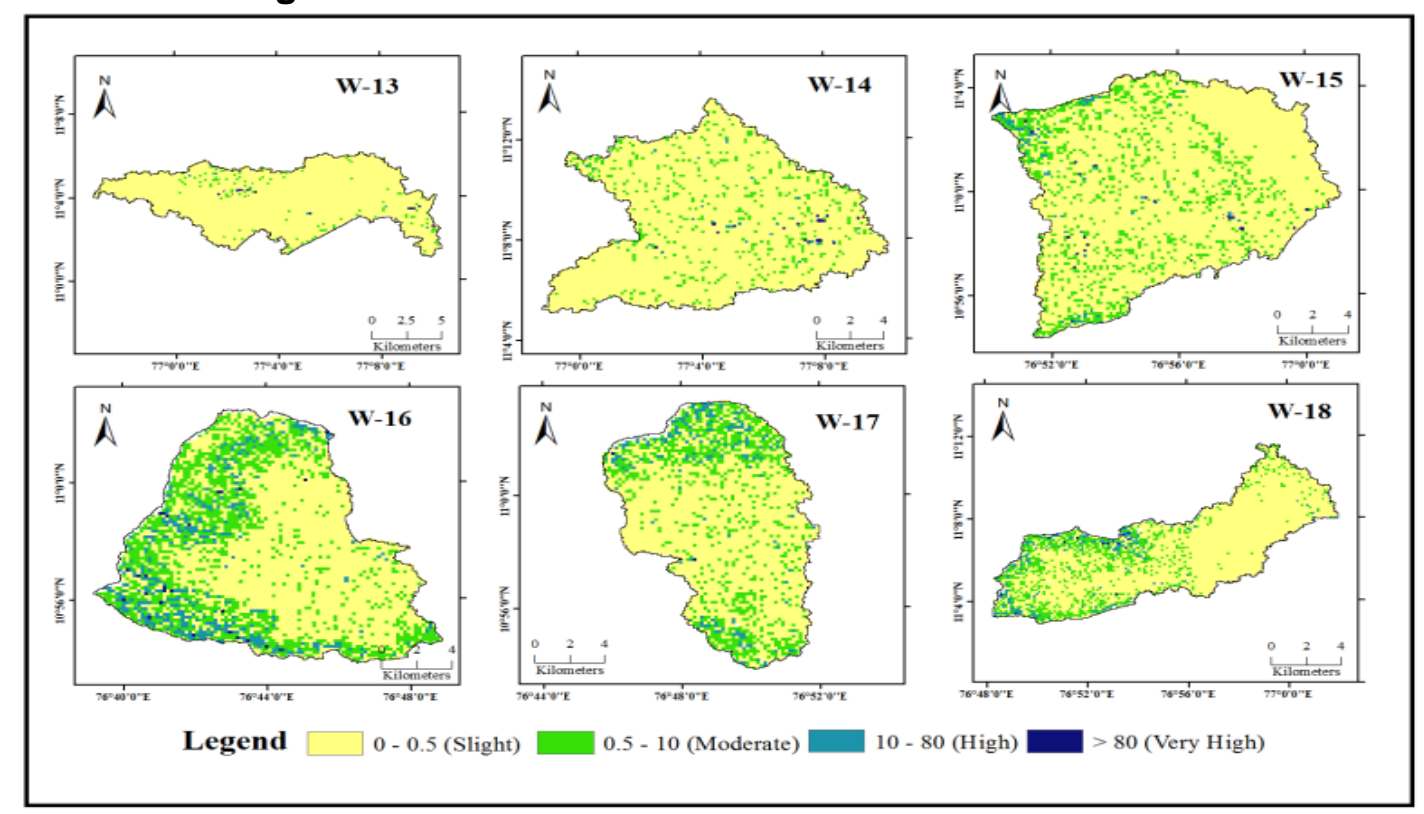

Table 06: Prioritization of Sub-Watersheds

\begin{tabular}{|c|c|c|c|c|}
\hline$\#$ & Sub - Watersheds & Area in sq. km. & Soil loss (T/ha_1_yr_1) & Ranking \\
\hline 1. & W1 & 276.9 & 238.78 & 2 \\
\hline 2. & W2 & 159.3 & 67.98 & 14 \\
\hline 3. & W3 & 260.9 & 124.36 & 10 \\
\hline 4. & W4 & 255.5 & 165.34 & 6 \\
\hline 5. & W5 & 158.2 & 44.4 & 16 \\
\hline 6. & W6 & 281.0 & 160.23 & 9 \\
\hline 7. & W7 & 128.4 & 20.78 & 18 \\
\hline 8. & W8 & 254.6 & 166.7 & 7 \\
\hline 9. & W9 & 139.8 & 38.18 & 17 \\
\hline 10. & W10 & 261.9 & 180.45 & 5 \\
\hline 11. & W11 & 107.5 & 216.49 & 12 \\
\hline 12. & W12 & 220.3 & 96.2 & 15 \\
\hline 13. & W13 & 123.9 & 47.15 & 11 \\
\hline 14. & W14 & 184.6 & 123.57 & 13 \\
\hline 15. & W15 & 230.9 & 89.47 & 1 \\
\hline 16. & W16 & 172.9 & 368.12 & 4 \\
\hline 17. & W17 & 129.4 & 187.11 & 8 \\
\hline 18. & W18 & 167.5 & 163.63 & \\
\hline & Total & 3513.2 & 2498.94 & \\
\hline
\end{tabular}

These sub-watersheds have been further grouped into priorities (Table 7) for soil erosion control treatment and results are presented in (Table 7) results. There are 5 sub-watersheds viz, W1, W10, W11, W16, W17 which are in high priority class, and hence require soil erosion control treatments at highest priority and cover $992 \mathrm{sq} . \mathrm{km}$. area of the watershed. There are 8 sub-watersheds with medium priority and 5 sub-watersheds with low priority.

Table 07: Categorization based on Priority Class of Sub-Watershed

\begin{tabular}{|c|l|l|c|}
\hline$\#$ & Soil Loss Classes (T/ha/Yr) & Sub - Watersheds & Priority Classes \\
\hline 1. & 0 to 80 & W2, W5, W7, W9, W13 & Low \\
\hline 2. & 80 to 180 & W3,W4,W6,W8,W12,W14,W15,W18 & Moderate \\
\hline 3. & Above 180 & W1,W10,W11,W16,W17 & High \\
\hline
\end{tabular}

\section{Conclusion}

In Noyyal River Basin, high soil erosion prone zone is observed in Western and Eastern part of the basin where the confluence of Noyyal and Cauvery rivers take place. The western part of the basin has high elevation resulting in high soil loss values compared to other parts of the basin. On contrary, low and moderate soil erosion zone are observed in the middle parts of the 
basin. The land use and land cover changes have an effect on the increasing soil erosion rate. The regions in western part of the map have higher soil erosion rate because of higher rainfall and higher slope. However, the values are under moderate category as the region is highly vegetation. Clearing of forests in this region may accelerate the soil erosion rate as the conservation practice adopted for this region is very minimal. Clearing of forests must be strictly avoided and afforestation must be practiced to ensure lower levels of soil erosion. Changes in crop patterns also have an effect on the change in rate of soil erosion. Conservation practices like terracing, agro-forestry, bunding, crop-rotation techniques etc. must be followed to minimize the rate of soil erosion. Majority of the region have lesser slope up to 8 degrees, and the amount of soil erosion is calculated to be in the lower to moderate levels. However, the rate of soil erosion can increase in future due to deforestation, over grazing etc. Thus, from this study, it is highly recommended that suitable soil conservation practice must be adopted everywhere possible, so that the amount of soil erosion can be kept under control preventing it from leading to soil degradation and increase of waste lands resulting in lesser production of crops.

Figure 13: Prioritization of Watersheds Based on Soil Erosion

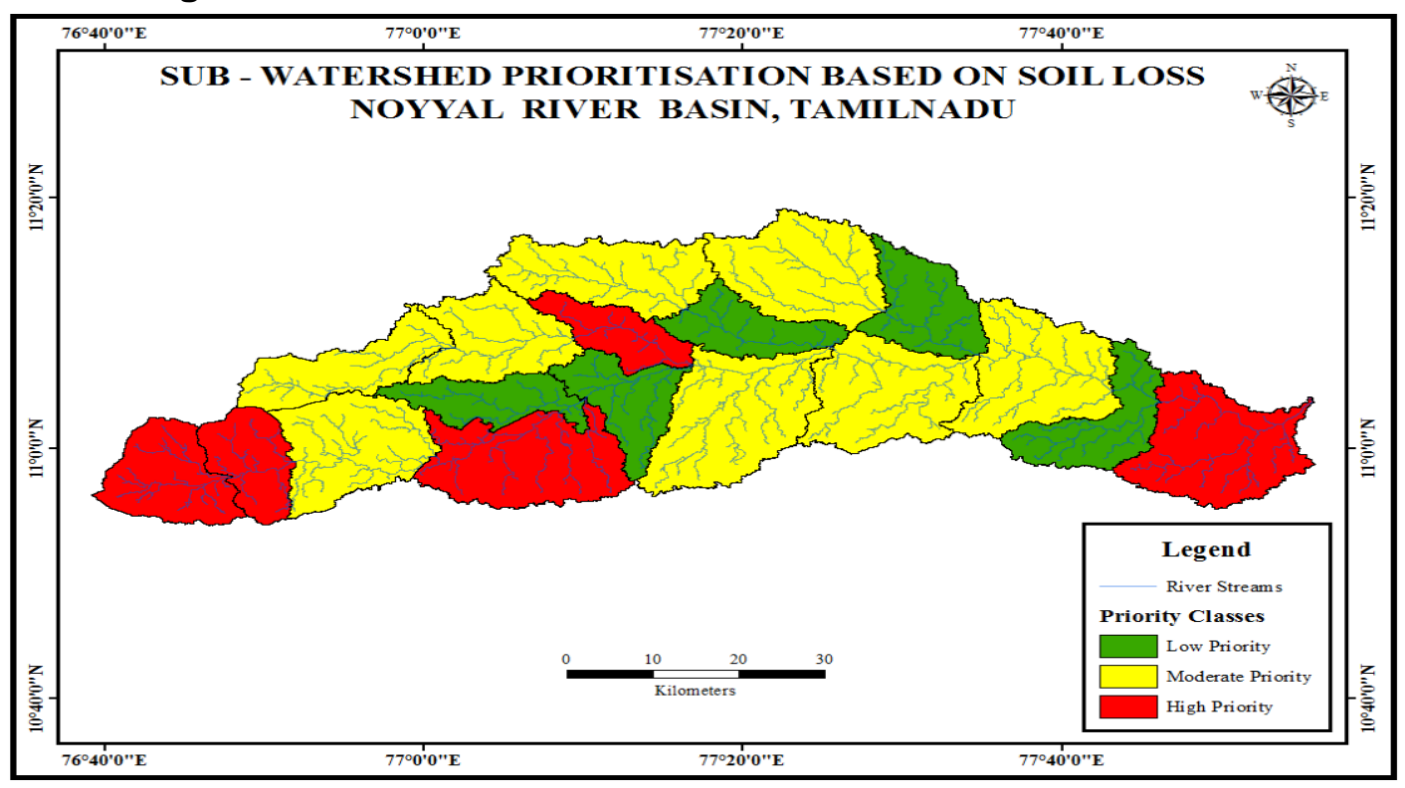

\section{References}

1. Asish Saha, Palash Ghosh, and Biswajit Mitra, (2018). "GIS Based Soil Erosion Estimation Using Rusle Model: A Case Study of Upper Kangsabati Watershed, West Bengal, India", "International Journal of Environmental science and natural resources"

2. Farhan Yahya, Zregat Dalal, (2013). "Spatial Estimation of Soil Erosion Risk Using RUSLE Approach, RS, and GIS Techniques: A Case Study of Kufranja Watershed", "Northern Jordan, Journal of Water Resource and Protection", 5, 1247-1261.

3. Ganasri BP, Ramesh H, (2016). "Assessment of soil erosion by RUSLE model using remote sensing and GIS- a case study of Nethravathi basin". Geosci Front 7(6): 953-961.

4. Hasan Raja Naqvi, et al., (2015). "Soil erosion planning using sediment yield index method in the Nun Nadi watershed", "India in International Soil and Water Conservation Research 3", (86-96).

5. Karthick P., C. Lakshumanan and P. Ramki, (2017). "Estimation of soil erosion vulnerability in Perambalur Taluk, Tamilnadu using (RUSLE) Model and geo information technology", "International Research Journal of Earth Sciences ISSN 2321 - 2527.

6. Narayan Kayet, Khanindra Pathak, Abhisek Chakrabarty and Satiprasad Sahoo, "Evaluation of soil loss estimation using the RUSLE model and SCS-CN method in hillslope mining areas", "International Soil and Water Conservation Research", (2018), 631-42.

7. Sahu Alka, et al., (2017). "Soil Erosion Modeling using Rusle and GIS on Dudhawa Catchment", "International Journal of Applied Environmental Sciences ISSN", 0973-6077.

8. Usha Chirala, et al., (2015). "Mapping of Soil Erosion Zones of Meghadrigedda Catchment, Visakhapatnam, India for Conservation: A Geospatial Approach", "International Journal of Geosciences" (326-338).

9. http://krishikosh.egranth.ac.in/

10. https://www.iwmi.cgiar.org/

11. http://www.isca.in/ 